"Natural disasters, information/communication technologies, foreign direct investment and economic growth in developed countries"

\begin{tabular}{|c|c|c|}
\hline \multirow{2}{*}{$\begin{array}{l}\text { AUTHORS } \\
\text { ARTICLE INFO }\end{array}$} & \multicolumn{2}{|l|}{$\begin{array}{l}\text { Nadia Benali } \\
\text { Rochdi Feki }\end{array}$} \\
\hline & \multicolumn{2}{|c|}{$\begin{array}{l}\text { Nadia Benali and Rochdi Feki (2018). Natural disasters, } \\
\text { information/communication technologies, foreign direct investment and economic } \\
\text { growth in developed countries. Environmental Economics, } 9(2), 80-87 \text {. } \\
\text { doi:10.21511/ee.09(2).2018.06 }\end{array}$} \\
\hline DOI & \multicolumn{2}{|c|}{ http://dx.doi.org/10.21511/ee.09(2).2018.06 } \\
\hline RELEASED ON & \multicolumn{2}{|l|}{ Friday, 06 July 2018} \\
\hline RECEIVED ON & \multicolumn{2}{|l|}{ Sunday, 27 May 2018} \\
\hline ACCEPTED ON & \multicolumn{2}{|l|}{ Thursday, 05 July 2018} \\
\hline LICENSE & \multicolumn{2}{|c|}{$\begin{array}{l}\text { This work is licensed under a Creative Commons Attribution-NonCommercial } 4.0 \\
\text { International License }\end{array}$} \\
\hline JOURNAL & \multicolumn{2}{|l|}{ "Environmental Economics" } \\
\hline ISSN PRINT & \multicolumn{2}{|l|}{$1998-6041$} \\
\hline ISSN ONLINE & \multicolumn{2}{|l|}{$1998-605 X$} \\
\hline PUBLISHER & \multicolumn{2}{|c|}{ LLC "Consulting Publishing Company "Business Perspectives" } \\
\hline FOUNDER & \multicolumn{2}{|c|}{ LLC "Consulting Publishing Company "Business Perspectives" } \\
\hline$\sigma^{\infty}$ & $B$ & 三:- \\
\hline NUMBER OF REFERENCES & NUMBER OF FIGURES & NUMBER OF TABLES \\
\hline 36 & 0 & 7 \\
\hline
\end{tabular}

(c) The author(s) 2022. This publication is an open access article. 
Nadia Benali (Tunisia), Rochdi Feki (Tunisia)

\title{
Natural disasters, information/communication technologies, foreign direct investment and economic growth in developed countries
}

\begin{abstract}
This paper investigates the causal relationship between natural disasters (DMS), information and communication technologies (ICT), foreign direct investment (FDI) and economic growth (GDP per capita) for 10 developed countries over the period 1990 to 2016. Panel DOLS and FMOLS results show that there is a positive relationship running from ICT to natural disasters and to foreign direct investment. In addition, ICT have a positive effect on GDP per capita. VECM Granger causality analysis results reveal a unidirectional causality in the short and long term from ICT to natural disaster and to FDI at the 5\% and 10\% levels. Therefore, one may note that there is a unidirectional relationship running from natural disaster to GDP and a bidirectional relationship between FDI and GDP.
\end{abstract}

Keywords: natural disasters, information/communication technologies, economic growth, panel data analysis.

JEL Classification: Q54, O16, C23.

Received on: $27^{\text {th }}$ of May, 2018.

Accepted on: $05^{\text {th }}$ of July, 2018.

\section{Introduction}

Natural disasters are gaining ground in terms of frequency, duration and disastrous consequences. They affect more than 300 million people each year worldwide and are considered as complex threats involving several factors simultaneously (Rim et al., 2012), hold back the development of countries and increase poverty.

During the last decade, the risks and costs of natural and man-made disasters have significantly increased. For example, in 2010, a 7.3 magnitude earthquake on the Richter scale devastated Haiti, killing more than 222000 people and leaving 300 000 injured, 1.2 million homeless in Port-au-Prince and more than 2 million displaced, especially in rural areas (United Nations Report, 2010).

In 2004, the most violent earthquake in the world after Chile in 1960 caused devastating tidal waves in part of the Indian Ocean, killed or disappeared more than 280000 people (Red Cross Report 2010). In fact, from 2002 to 2011, there were 4130 natural hazard disasters in the world, resulting in at least $\$ 1$ 195 billion in economic losses (UNISDR, 2015). Losses from natural disasters were estimated at \$ 150 billion in 2010 (Becklumb, 2010).

In view of all this, governments around the world, civil society actors, scientists, development and humanitarian aid organizations, local communities

\footnotetext{
(C) Nadia Benali, Rochdi Feki, 2018.

Nadia Benali, Ph.D., Doctor in Economics, Faculty of Economics and Management, University of Sfax, Sfax, Tunisia.

Rochdi Feki, Professor, Sfax Business School, University of Sfax, Tunisia.

This is an Open Access article, distributed under the terms of the Creative Commons Attribution 4.0 Internationallicense which permits unrestricted re-use, distribution, and reproduction in any medium, provided the original work is properly cited
}

that are most affected, etc., should take the consequences of disasters seriously and invest in developing disaster prevention and resilience capacities.

In addition, the world will be forced to accept the need for a coordinated and collaborative use of new communication technologies in the disaster management. The use of information and communication technologies (ICTs) is helping to strengthen disaster resilience through good climate science and information sharing. When an earthquake occurs, for example, a coordinated ICT system can monitor developments, send emergency messages and assist affected populations.

This paper examines the relationships between Information Communication Technology, natural disasters, Foreign Direct Investment and GDP per capita for 10 developed countries over the period 1990 to 2016. Panel DOLS and FMOLS and Granger causality-VECM approach are used to investigate the short- and long-run relationship between variables and to reveal the direction of causality among them.

The paper is organized as follows. Section 1 presents an overview of literature, section 2 presents the data and the methodology, the empirical results are in Section 3 and the last section presents a summary of the results and draws conclusions.

\section{Literature review}

Skidmore and Toya (2002) revealed a positive correlation between natural disasters, human capital investment and factors of production. In addition, the occurrence of natural disasters encourages the adoption of new technologies and consequently leads to an increase in the factors 
of production in the long term. Cuaresma et al. (2008) and Hallegatte and Dumas (2009) showed that natural disasters do not affect long-term economic growth. The empirical results of Cavallo and Noy (2010) and Sawada et al. (2011) indicated that there is a negative relationship from natural disasters to economic growth. Cuñado and Ferreira (2014) used panel vector autoregression models, and showed that flood shocks have a positive impact on per capita GDP growth. In another study, Anuchitworawong and Thampanishvong (2015) investigated the effect of natural disaster on FDI. They found that an increase in severity of natural disaster leads to a decrease of FDI flows into Thailand. Benali et al. (2016, 2017) showed that there is a unidirectional relationship from natural disasters to budget deficit. Benali and Saidi (2017) have tested the relationship between natural disaster, economic growth, physical capital, labor and electricity for 41 countries. They showed that for African countries, natural disaster has a negative effect on all variables, for American countries, disaster measures have a negative and significant effect on economic growth and consumption electricity, and for European countries, there is a unidirectional relationship from the disaster measures to labor and from the disaster measures to electricity consumption. In reality, few studies have examined the role of ICT in the production of a common history of risk. In this regard, Shklovski et al. (2008) showed the importance of using ICT to solving the problems of catastrophic events.
Samarajiva and Waidyanatha (2009) indicated that using mobile application helps Asian government overcome difficulties caused by natural disasters. According to John et al. (2015), ICTs are instrumental in the recovery after the earthquake in Japon. Their use increases the level of social capital and civic participation. Toya and Skidmore (2015) examined the relationship between ICT and disaster fatalities. By using a panel data model over the 1980-2013 period, they showed that ICTs help to minimize the number of fatalities following disaster events.

\section{Data description and methodology}

2.1. Data description. Data on GDP per capita (GDP) (constant 2005 US\$), foreign direct investment and information and communication technology (ICT) include mobile cellular subscriptions and internet users downloaded from the World Bank Data. Data on natural disasters are obtained from the EM-DAT. The specific countries selected for the study are Australia, Canada, France, Germany, Italy, Japan, Spain, Suisse, the United Kingdom, and the United States over the period 1990 to 2016.

The measurement of natural disasters is based on three factors: the number of people killed, the number of people affected and the amount of economic damage. According to Noy (2009), the measurement of natural disaster (DM) is calculated as follows:

$$
\begin{aligned}
\text { (1) Total population affected } & =\left[\sum_{j=1}^{N}\left(\frac{\text { total population affected }_{\mathrm{ijt}}}{\text { total population }_{\mathrm{i}, \mathrm{t}}}\right)\right], \\
\text { (2) Total population killed } & =\left[\sum_{\mathrm{j}=1}^{\mathrm{N}}\left(\frac{\text { total people killed }_{\mathrm{ijt}}}{\text { total population }_{\mathrm{i}, \mathrm{t}}}\right)\right], \\
\text { (3) Economic damage } & =\left[\sum_{\mathrm{j}=1}^{\mathrm{N}}\left(\frac{\text { damage }_{\mathrm{ijt}}}{\text { total GDP }_{\mathrm{i}, \mathrm{t}}}\right)\right]
\end{aligned}
$$

where $i$ denotes the country, $j$ represents the natural disaster (drought, floods, earthquake and storms) and $t=1, \ldots, \mathrm{N}$ indicates the year. The disaster measures (DMS) are calculated as follows:

$$
\mathrm{DMS}=\mathrm{DM} \frac{(12-\text { month })}{12}
$$


Table 1. Descriptive analysis

\begin{tabular}{|l|l|l|l|l|l|}
\hline Designations & DMS & FDI & GDP & INT & MOB \\
\hline Mean & 9.296636 & 24.33731 & 28.59990 & 5.817559 & 4.619739 \\
\hline Median & 0.000000 & 24.41079 & 28.44392 & 6.170566 & 4.658163 \\
\hline Maximum & 287.0400 & 26.95012 & 30.45760 & 7.615198 & 5.115002 \\
\hline Minimum & 0.000000 & 17.36548 & 27.55213 & 0.959658 & 3.255843 \\
\hline Std. Dev. & 30.57922 & 1.289830 & 0.745525 & 1.482024 & 0.290700 \\
\hline Skewness & 6.410964 & -1.446996 & 1.127144 & -1.291834 & -1.089863 \\
\hline Kurtosis & 52.80463 & 9.066193 & 3.531894 & 4.460448 & 5.920181 \\
\hline Jarque-Bera & 15428.60 & 263.5143 & 31.29424 & 51.01441 & 77.45886 \\
\hline
\end{tabular}

2.2. Methodology of the study. In this section, the necessary tests are presented. First, the heterogeneous unit root test, the cointegration for the panel data, the panel DOLS and FMOLS estimates and then the Granger causality test are exlained.
2.2.1. Panel unit root tests. In order to apply the panel cointegration test as time series, the stationarity test must be used.

To consider the panel unit root, one can apply the following autoregressive model:

$$
Y_{i t}=\rho_{1 i} Y_{i t-1}+\delta_{i} X_{i t}+\varepsilon_{i t},
$$

where $i 1,2, \ldots, \mathrm{N}$ is the series for country, $t 1,2$, ..., $T$ indicates the time, $X$ exposes the exogenous variables, $\quad p$ indicates the autoregressive coefficient, and $\varepsilon_{i}$ is the error term. If $\left|p_{i}\right|=1, Y_{i}$ has the unit root. Levin, Lin, and Chu (LLC) (2002) adopted the assumption of a homogeneous coefficient for all panels. However, Im, Pesaran and Shin (IPS)'s (2003) tests, Fisher-ADF and Fisher-PP tests were conducted by the assumption of a heterogeneous coefficient (Costantini \& Martini, 2010).

$$
\Delta \gamma_{\mathrm{it}}=\alpha_{\mathrm{i}}+\beta_{\mathrm{i}} \gamma_{\mathrm{it}-1}+\sum_{\mathrm{j}=1}^{p_{i}} \rho_{\mathrm{ij}} \Delta \gamma_{\mathrm{it}-1}+\varepsilon_{\mathrm{it}}
$$

where $\Delta$ is the first-difference operator, $\mathrm{p}_{-} \mathrm{i}$ is the ag order in the $\mathrm{ADF}$ regression.

Null hypotheses and alternatives can be written as follows:

$$
\begin{gathered}
\mathrm{H}_{0}: \beta_{i}=0, \forall i \\
\mathrm{H}_{1}=\left\{\begin{array}{c}
\beta_{\mathrm{i}}=0<1 \text { pour certai } i^{\prime} s \\
\beta_{\mathrm{i}}<0 \exists i
\end{array}\right.
\end{gathered}
$$

2.2.2. Panel cointegration test. In general, cointegration tests are performed on time series. However, Pedroni (1999) and Kao (1999) have proposed cointegration tests that apply to longitudinal data. The use of cointegration techniques in panel data makes it possible to test the presence of long-term relationships between integrated variables. The test developed by Pedroni (1999) is part of the tests based on the residue. He considers the following regression model:

$$
\begin{gathered}
\mathrm{GDP}_{\text {it }}=\alpha_{\mathrm{i}}+\beta_{1 \mathrm{i}} \mathrm{DMS}_{\text {it }}+\beta_{2 \mathrm{i}} \mathrm{FDI}_{\text {it }}+\beta_{3 \mathrm{i}} \mathrm{MOB}_{\text {it }}+\beta_{4 \mathrm{i}} \mathrm{INT}_{\text {it }}+\varepsilon_{\text {it }} \\
\mathrm{t}=1, \ldots . ., \mathrm{T} \text { et } \mathrm{i}=1, \ldots \ldots . \mathrm{N},
\end{gathered}
$$

Where $t$ denotes the time and $i$ is the number of individuals, $\beta_{1 i}, \beta_{2 i}, \beta_{3 i}, \beta_{4 i}$, and $\alpha_{i}$ are parameters to estimate.

To better take into account the degree of interindividual dimension.

$$
\hat{\varepsilon}_{i t}=\rho_{1 i} \varepsilon_{i t-1}+u_{i t}
$$

The differentiation between intra- and interindividual dimensions is made at the level of heterogeneity of the panel, Pedroni (1997, 1999) suggests seven tests: four are based on the intraindividual dimension and three on the alternative hypothesis formulation. Tests are based on the intra-individual dimension 
formulating alternative hypothesis $H_{1}: p_{i}=p<1$. hypothesis $\quad$ is $\quad$ spelled $\quad H_{1}: p_{i}<1$. In the inter-individual dimension, alternative

$$
\begin{aligned}
& \rho_{\mathrm{i}}=\rho<1 \forall \mathrm{i} \text { : within } \\
& \rho_{\mathrm{i}}<1 \forall \mathrm{i} \text { : between }
\end{aligned}
$$

In contrast to Pedroni tests, Kao considers the special case, in which co-integration vectors are supposed to be homogeneous among individuals. In other words, these tests do not make it possible to consider heterogeneity under the alternative hypothesis and are otherwise valid only for a bivaried system.

2.2.3. Panel DOLS and FMOLS estimates. Having proved that all variables are stationary in first differences and the long-term cointegration in the preceding steps exists, one can apply the estimation tests of these long-term panel relationships using the methods of FMOLS and DOLS estimators proposed by Pedroni (2001) and Mark and Sul (2002). The FMOLS and DOLS estimates generally give different results.

2.2.4. Panel causality tests. After establishing the existence of cointegration relationship, in order to study the long-term causal relationship between variables, one can use the Granger causality test (Granger, 1988). If the cointegration relationship is confirmed, Vector Error Correction (VECM) Granger causality test can be applied.

$$
\begin{aligned}
\Delta G D P_{i t}= & \beta_{1}+ \\
+ & \sum_{i=1}^{P} \beta_{1 i} \Delta G D P_{i t-k}+\sum_{i=1}^{P} \beta_{1 i} \Delta D M S_{i t-k}+\sum_{i=1}^{P} \beta_{1 i} \Delta F D I_{i t-k} \\
& +\sum_{i=1}^{P} \beta_{1 i} \Delta M O B_{i t-k}+\sum_{i=1}^{P} \beta_{1 i} I N T_{i t-k}+\delta_{1} E C T_{i t-1}+\varepsilon_{1 i t} \\
\Delta F D I_{i t}= & \beta_{2}+\sum_{i=1}^{P} \beta_{2 i} \Delta F D I_{i t-k}+\sum_{i=1}^{P} \beta_{2 i} \Delta D M S_{i t-k}+\sum_{i=1}^{P} \beta_{3 i} \Delta G D P_{i t-k} \\
& +\sum_{i=1}^{P} \beta_{4 i} \Delta M O B_{i t-k}+\sum_{i=1}^{P} \beta_{5 i} I N T_{i t-k}+\delta_{2} E C T_{i t-1}+\varepsilon_{2 i t} \\
\Delta M O B_{i t}= & \beta_{3}+\sum_{i=1}^{P} \beta_{3 i} \Delta M O B_{i t-k}+\sum_{i=1}^{P} \beta_{3 i} \Delta D M S_{i t-k}+\sum_{i=1}^{P} \beta_{3 i} \Delta G D P_{i t-k} \\
& +\sum_{i=1}^{P} \beta_{3 i} \Delta F D I_{i t-k}+\sum_{i=1}^{P} \beta_{3 i} I N T_{i t-k}+\delta_{3} E C T_{i t-1}+\varepsilon_{3 i t} \\
+\sum_{i=1}^{P} \beta_{4 i} \Delta F D I_{i t-k}+\sum_{i=1}^{P} \beta_{4 i} M O B_{i t-k}+\delta_{4} E C T_{i t-1}+\varepsilon_{4 i t} & \\
& +\sum_{i=1}^{P} \beta_{4 i} \Delta I N T_{i t-k}+\sum_{i=1}^{P} \beta_{4 i} \Delta D M S_{i t-k}+\sum_{i=1}^{P} \beta_{4 i} \Delta G D P_{i t-k} \\
\beta_{4} &
\end{aligned}
$$


where $\Delta$ is the first difference operator, ECT presents the error correction term.

\section{Empirical results}

3.1. Panel unit root results. The results of the unit root tests from Table 2 show that the GDP, DMS, FDI, MOB and INT are not stationary in level, but

stationary in first difference (Table 3). Given that all variables are integrated for order 1 I (1), the long-term relationship between these variables is possible

Table 2. Panel unit root tests results: series in level

\begin{tabular}{|c|c|c|c|c|c|c|c|c|c|c|}
\hline & \multicolumn{2}{|c|}{ GDP } & \multicolumn{2}{|c|}{ DMS } & \multicolumn{2}{|c|}{ FDI } & \multicolumn{2}{|c|}{ MOB } & \multicolumn{2}{|c|}{ INT } \\
\hline & Intercept & Trend & Intercept & Trend & Intercept & Trend & Intercept & Trend & Intercept & Trend \\
\hline LLC & $\begin{array}{r}-1.42516 \\
(0.0771)\end{array}$ & $\begin{array}{l}-2.84495 \\
(0.0022)^{\star *}\end{array}$ & $\begin{array}{r}-2.34097 \\
(0.2196)\end{array}$ & $\begin{array}{l}-1.32403 \\
(0.0927)^{* * *}\end{array}$ & $\begin{array}{r}-2.74388 \\
(0.2530)\end{array}$ & $\begin{array}{c}-4.16033 \\
(0.9827)\end{array}$ & $\begin{array}{c}-3.05953 \\
(1.0000)\end{array}$ & $\begin{array}{r}-5.20898 \\
(0.1249)\end{array}$ & $\begin{array}{l}-7.31763 \\
(0.0000)^{*}\end{array}$ & $\begin{array}{l}-5.50126 \\
(0.0000)^{*}\end{array}$ \\
\hline IPS & $\begin{array}{l}0.80224 \\
(0.7888)\end{array}$ & $\begin{array}{c}-0.88262 \\
(0.1887)\end{array}$ & $\begin{array}{c}-2.48549 \\
(0.3465)\end{array}$ & $\begin{array}{c}-0.37843 \\
(0.3526)\end{array}$ & $\begin{array}{r}-0.47633 \\
(0.3169)\end{array}$ & $\begin{array}{l}0.88915 \\
(0.8130)\end{array}$ & $\begin{array}{r}-3.51597 \\
(0.1651)\end{array}$ & $\begin{array}{r}-1.62189 \\
(0.2135)\end{array}$ & $\begin{array}{l}3.54364 \\
(0.8742)\end{array}$ & $\begin{array}{r}-1.44455 \\
(1.0000)\end{array}$ \\
\hline ADF & $\begin{array}{c}13.8441 \\
(0.8383)\end{array}$ & $\begin{array}{l}23.3895 \\
(0.2701)\end{array}$ & $\begin{array}{c}35.2602 \\
(0.0088)^{*}\end{array}$ & $\begin{array}{c}5.3934 \\
(0.1868)\end{array}$ & $\begin{array}{l}24.0917 \\
(0.2384)\end{array}$ & $\begin{array}{c}3.5978 \\
(0.8503)\end{array}$ & $\begin{array}{c}4.9427 \\
(0.9992)\end{array}$ & $\begin{array}{l}31.4102 \\
(0.6502)\end{array}$ & $\begin{array}{l}47.7904 \\
(0.9628)\end{array}$ & $\begin{array}{l}30.1729 \\
(0.8671)\end{array}$ \\
\hline PP & $\begin{array}{l}37.8855 \\
(0.0091)^{*}\end{array}$ & $\begin{array}{c}31.4779 \\
(0.0492)^{*}\end{array}$ & $\begin{array}{l}93.2405 \\
(0.3012)\end{array}$ & $\begin{array}{c}11.296 \\
(0.0000)^{*}\end{array}$ & $\begin{array}{c}6.0298 \\
(0.0000)^{*}\end{array}$ & $\begin{array}{c}5.3163 \\
(0.3680)\end{array}$ & $\begin{array}{c}3.924 \\
(0.9999)\end{array}$ & $\begin{array}{l}59.0282 \\
(0.9992)\end{array}$ & $\begin{array}{l}65.9529 \\
(0.3112)\end{array}$ & $\begin{array}{l}56.2540 \\
(0.1000)\end{array}$ \\
\hline
\end{tabular}

Note: $* * *$, and $* * *$ represent significance at the $1 \%, 5 \%$, and $10 \%$ levels, respectively.

Table 3. Panel unit root tests results: series in first difference

\begin{tabular}{|c|c|c|c|c|c|c|c|c|c|c|}
\hline & \multicolumn{2}{|c|}{$\mathrm{D}(\mathrm{GDP})$} & \multicolumn{2}{|c|}{$\mathrm{D}$ (DMS) } & \multicolumn{2}{|c|}{$\mathrm{D}(\mathrm{FDI})$} & \multicolumn{2}{|c|}{$\mathrm{D}(\mathrm{MOB})$} & \multicolumn{2}{|c|}{$\mathrm{D}(\mathrm{INT})$} \\
\hline & Intercept & Trend & Intercept & Trend & Intercept & Trend & Intercept & Trend & Intercept & Trend \\
\hline \multirow{2}{*}{ LLC } & 5.48235 & -5.33025 & -2.45232 & 0.03410 & -5.15333 & -7.48349 & -4.83356 & -2.18391 & -2.91279 & -2.21300 \\
\hline & $(0.0000)^{*}$ & $(0.0000)^{*}$ & $(0.0071)^{*}$ & $(0.5136)$ & $(0.0000)^{*}$ & $(0.0000)^{*}$ & $(0.0000)^{*}$ & $(0.0145)^{* *}$ & $(0.0018)^{*}$ & $(0.0134)^{*}$ \\
\hline \multirow{2}{*}{ IPS } & -3.05673 & -0.91920 & -4.44500 & -2.76438 & -2.18159 & -2.23646 & -1.94114 & 0.73352 & -4.59415 & -2.44480 \\
\hline & $(0.0011)$ & $(0.0790)$ & $(0.0000)^{*}$ & $(0.0029)^{*}$ & $(0.0146)^{* *}$ & $(0.0127)^{* *}$ & $(0.0261)^{* *}$ & $(0.0684)$ & $(0.0000)^{*}$ & $(0.0072)^{*}$ \\
\hline \multirow{2}{*}{ ADF } & 41.3836 & 24.4258 & 61.3996 & 42.6016 & 34.5075 & 42.2772 & 31.4052 & & 572473 & 374337 \\
\hline & $(0.0033)$ & $(0.0243)$ & $(0.0000)^{*}$ & $(0.0023)^{*}$ & $(0.0229)^{* *}$ & $(0.0025)^{*}$ & $(0.0501)^{* *}$ & ) & $(0.0000)^{*}$ & $(0.0104)^{*}$ \\
\hline \multirow[b]{2}{*}{ PP } & & & & & & & 60.4827 & & & \\
\hline & $(0.0000)$ & $(0.0011)^{*}$ & $(0.0000)^{*}$ & $(0.0000)^{*}$ & $(0.0005)^{*}$ & $(0.0000)^{*}$ & $(0.0000)^{*}$ & $\begin{array}{l}20.0070 \\
(0.01534)\end{array}$ & $(0.0000)^{*}$ & $(0.0000)^{*}$ \\
\hline
\end{tabular}

Note: $* * *$, and $* * *$ represent significance at the $1 \%, 5 \%$, and $10 \%$ levels, respectively.

3.2. Panel cointegration test results. Table 4 reports the results of Pedroni co-integration test statistics. The majority of those tests indicate the existence of a cointegration relationship. In addition, Kao test result (Table 5) shows that there is a strong evidence of longrun cointegration relationship between variables.

Table 4. Pedroni cointegration test

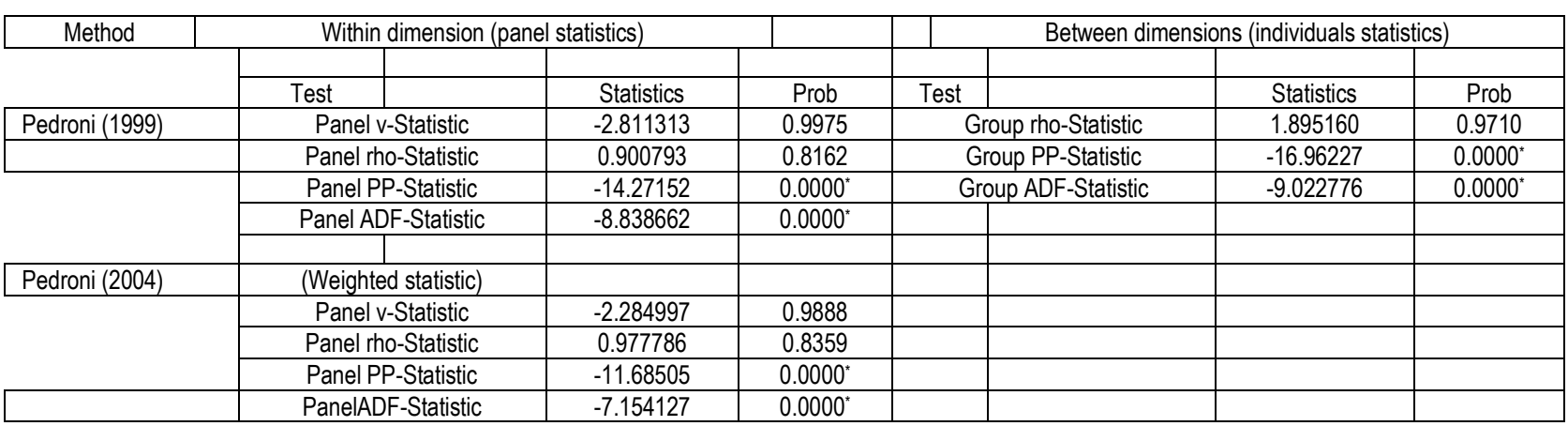

Note: The null hypothesis is that the variables are not cointegrated. * indicates the rejection of the null hypothesis at $5 \%$. 
Table 5. Kao residual cointegration test result

\begin{tabular}{|l|l|l|}
\hline Model specification: No deterministic trend & t-Statistic & Prob. \\
\hline ADF t-statistics & -8.814367 & $0.0000^{+}$ \\
\hline
\end{tabular}

3.3. DOLS and FMOLS results. This sub-section presents the estimation of the long-term impact of all explanatory variables on the GDP per capita in
10 countries. The results of the panel FMOLS estimator are not similar to the DOLS estimators in all cases; all results are presented in Table 6.

Table 6. FMOLS and DOLS

\begin{tabular}{|c|c|c|c|c|c|}
\hline \multirow[b]{3}{*}{ Dependent variables } & \multirow[b]{3}{*}{ Independent variables } & \multicolumn{4}{|l|}{ Panel group } \\
\hline & & \multicolumn{2}{|l|}{ FMOLS } & \multicolumn{2}{|l|}{ DOLS } \\
\hline & & Coefficient & Prob & Coefficient & Prob \\
\hline \multirow[t]{4}{*}{ DGDP } & DDMS & -4.08120 & $0.0378^{*}$ & -2.00498 & $0.0000^{*}$ \\
\hline & DFDI & 10.43789 & $0.0292^{*}$ & 0.032201 & $0.0207^{*}$ \\
\hline & DMOB & 9.64637 & $0.0003^{*}$ & -0.307186 & 0.1880 \\
\hline & DINT & 12.02363 & $0.0288^{*}$ & 0.096969 & 0.0295 \\
\hline \multirow[t]{4}{*}{ DFDI } & DDMS & 0.000766 & 0.6606 & -0.043789 & 0.2576 \\
\hline & DGDP & 12.53303 & $0.0004^{*}$ & -6.127486 & 0.3401 \\
\hline & DMOB & 0.502733 & $0.0076^{*}$ & 2.609391 & $0.0365^{*}$ \\
\hline & DINT & 0.242251 & $0.0103^{*}$ & 0.044097 & $0.0556^{*}$ \\
\hline \multirow[t]{4}{*}{ DMOB } & DGDP & 35.54141 & 0.3861 & 1.234080 & $0.0154^{*}$ \\
\hline & DDMS & 0.000198 & 0.2194 & 0.003379 & 0.2956 \\
\hline & DFDI & -0.001513 & 0.8066 & -0.005989 & 0.8289 \\
\hline & DINT & 0.022178 & 0.6970 & 0.122110 & $0.0057^{*}$ \\
\hline \multirow[t]{4}{*}{ DINT } & DGDP & 0.752953 & 0.2776 & 3.144133 & $0.0370^{*}$ \\
\hline & DDMS & 0.000511 & 0.1329 & -0.013181 & 0.2927 \\
\hline & DFDI & -0.012724 & 0.3275 & -0.105731 & 0.4904 \\
\hline & $\mathrm{DMOB}$ & -0.015980 & 0.9501 & 2.551554 & $0.0042^{*}$ \\
\hline \multirow[t]{4}{*}{ DDMS } & DGDP & -167.0814 & 0.1399 & -806.1912 & $0.0000^{*}$ \\
\hline & DFDI & 1.168724 & 0.5814 & 3.462353 & 0.5448 \\
\hline & $\mathrm{DMOB}$ & -1.478470 & $0.0000^{*}$ & 254.2503 & $0.0000^{*}$ \\
\hline & DINT & -36.85091 & $0.0569^{*}$ & -6.371243 & 0.8005 \\
\hline
\end{tabular}

Note: * indicates statistical significance at the $5 \%$ level.

In Table 6, FMOLS test shows a positive relationship running from mobile cellular and internet users to GDP per capita, at $5 \%$ of significance. This means that, a $1 \%$ increase in mobile cellular and internet leads to increase in GDP per capita by $9.6 \%$ and $12 \%$, respectively. The results are consistent with Stanley et al. (2015). Mobile cellular and internet users are further stimulate economic growth. This is due to the role of ICT in improving the functioning of markets, reducing transaction costs and increasing productivity through better management. Besides, $1 \%$ increase in disaster measure leads to a decrease in GDP by $4 \%$. Natural disasters tend to cause a series of major economic upheavals. It reduces production and number of hours worked. Reconstruction efforts compensate part of these losses and, paradoxically, stimulating effect on economic growth. In addition, it is shown that there is a positive link between foreign direct investment and GDP per capita. This implies that foreign direct investment has an important part to play in the acceleration of economic growth in developed countries. Furthermore, the effects of Internet and mobile cellular on natural disaster event and foreign direct investment are positive and statistically significant at the 5\% level. Using mobile cellular and Internet can help people in preventing and moderating the serious impact of disasters. In addition, ICT stimulates foreign investment; these results are similar to Fakher (2016). Panel DOLS results indicate that a $1 \%$ increase in DMS leads to a decrease in GDP per capita by $2 \%$. In addition, an increase in ICT leads to an increase in FDI.

3.4. Panel causality tests results. Results are reported in Table 7. One can deduce the meaning of causal relationships that may appear between the variables at the critical level of $5 \%$. 
Table 7. The VECM Granger causality

\begin{tabular}{|c|c|c|c|c|c|c|}
\hline Short run & & & & & & Long run \\
\hline & DMS & GDP & FDI & MOB & INT & $E C M_{t-1}$ \\
\hline DMS & 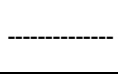 & $\begin{array}{c}27.89730 \\
(0.0000)^{*}\end{array}$ & $\begin{array}{l}0.135797 \\
(0.9344)\end{array}$ & $\begin{array}{c}0.398904 \\
(0.8192)\end{array}$ & $\begin{array}{l}3.610625 \\
(0.1644)\end{array}$ & $\begin{array}{l}37.86786 \\
(0.0000)^{*}\end{array}$ \\
\hline GDP & $\begin{array}{c}4.899453 \\
(0.1863)\end{array}$ & - & $\begin{array}{l}0.658770 \\
(0.0194)^{*}\end{array}$ & $\begin{array}{l}16.41732 \\
(0.0003)^{*}\end{array}$ & $\begin{array}{l}9.689010 \\
(0.0079)^{*}\end{array}$ & $\begin{array}{l}15.87895 \\
(0.0441)^{*}\end{array}$ \\
\hline FDI & $\begin{array}{c}0.207688 \\
(0.9014)\end{array}$ & $\begin{array}{l}5.152506 \\
(0.0761)^{* *}\end{array}$ & $\ldots$ & $\begin{array}{c}4.110949 \\
(0.1280)\end{array}$ & $\begin{array}{c}2.767809 \\
(0.2506)\end{array}$ & $\begin{array}{c}.482585 \\
(0.9005)\end{array}$ \\
\hline MOB & $\begin{array}{l}11.94869 \\
(0.0025)^{*} \\
\end{array}$ & $\begin{array}{l}3.945317 \\
(0.1391) \\
\end{array}$ & $\begin{array}{l}1.135454 \\
(0.0668)^{* *} \\
\end{array}$ & 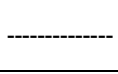 & $\begin{array}{l}0.599846 \\
(0.7409) \\
\end{array}$ & $\begin{array}{l}51.61618 \\
(0.0000)^{*}\end{array}$ \\
\hline INT & $\begin{array}{c}28.52297 \\
(0.0000)^{*}\end{array}$ & $\begin{array}{c}2.834582 \\
(0.2424)\end{array}$ & $\begin{array}{l}1.588610 \\
(0.0519)^{*}\end{array}$ & $\begin{array}{c}1.925118 \\
(0.3819)\end{array}$ & -.- & $\begin{array}{l}19.93186 \\
(0.0106)^{*}\end{array}$ \\
\hline
\end{tabular}

Note: *, ** mean significance at the $5 \%$ and $10 \%$ levels, respectively.

The results show that there is a unidirectional causality in the short and long term from mobile cellular and internet users to natural disaster and to FDI. The conclusion that may be drawn from these results is that information and communication technologies can play a vital role in preservation of human life and reduction of recovery costs. Furthermore, result reveals that there is a unidirectional causality from natural disaster to GDP per capita. Capital assets and infrastructure, such as homes, schools, factories and equipment, roads, dams and bridges are destroyed following natural disasters. Human capital is reduced because of loss of life, loss of workers. Cyclical natural disasters can lead to a decrease in production, which leads to economic losses. Finally, there is a bidirectional causality relationship between FDI and GDP. This finding is consistent with Hansen and Rand (2006), Miankhel et al. (2009), Omri and Kahouli (2014), Majid Mahmoodia and Elahe Mahmoodib (2016). On the one hand, FDI can be considered as capital injections to revitalize the economy, on the other hand, economic growth is considered as a tool to stimulate foreign direct investment.

\section{Conclusion}

In this paper, the objective has been to use the Panel
DOLS and FMOLS and Granger causality-VECM approach to characterize the relationship between natural disasters (DMS), information and communication technologies (ICT), foreign direct investment (FDI) and economic growth (GDP per capita). The study was carried out on a sample of 10 developed countries over the period 1990 to 2016. Results of FMOLS and DOLS showed that mobile cellular and internet users have a positive effect on GDP per capita and natural disaster event. In addition, natural disaster has a negative impact on GDP per capita. Results of VECM Granger causality test indicated that there is a unidirectional causality in the short and long term from ICT to natural disaster and to FDI at the 5\% and 10\% levels. Therefore, it was noted that there is a unidirectional causality from natural disaster to GDP and a bidirectional causality between FDI and GDP.

To avoid the consequences of disaster events, the ICT is an important learning phenomenon in the occurrence of disasters by reducing uncertainty of natural hazards. When they represent a simple information dissemination technology, digital tools are mainly used to configure alerts, establish diagnoses and record activity traces. Similarly, ICTs play a key role in accelerating the potential for economic growth, generating productivity gains of their own.

\section{References}

1. Anuchitworawong, H., \& Thampanishvong, K. (2015). Determinants of foreign direct investment in Thailand: Does natural disaster matter? International Journal of Disaster Risk Reduction, 14, 312-321.

2. Becklumb, (2010). Changements climatiques et migrations forcée, le rôle du Canada. Parlement du Canada.

3. Benali N., \& Saidi. K. (2017). A robust analysis of the relationship between natural disasters, electricity and economic growth in 41 countries. Journal of Economic Development, 42, 3.

4. Benali, N., \& Abdelkafi, I., \& Feki, R. (2018). Natural-disaster shocks and government's behavior: Evidence from middle income Countries. International Journal of Disaster Risk Reduction, 27, 1-6.

5. Benali, N., Ben Mbarek, M., \& Feki, R. (2017). Natural Disaster, Government Revenues and Expenditures: Evidence from High and Middle-Income Countries. Journal of the Knowledge Economy, 1-16.

6. Cavallo E., \& Noy, I. (2010). The Economics of Natural Disasters: A Survey (IDB Working Paper series 124).

7. Costantini, V., \& Martini, C. (2010). The causality between energy consumption and economic growth: a multisectoral analysis using non-stationary cointegrated panel data. Energy Economics, 32, 591-603. 
8. Cuaresma, J. C., Hlouskova, J., \& Obersteiner, M. (2008). Natural Disasters as Creative Destruction? Evidence from Developing Countries. Economic Inquiry, 46, 214-226.

9. Cuñado, J., \& Ferreira, S. (2014). The macroeconomic impacts of natural disasters: the case of floods. Land Econ., 90(1), 149-168.

10. Fakher, A. (2016). The Impact of Investment in ICT Sector on Foreign Direct Investment: Applied Study on Egypt. Review of Integrative Business and Economics Research, 5(2), 151-166.

11. Granger, C. W. J. (1988). Causality, cointegration and control. Journal of Economic Dynamics and Control, 12 , 551-559.

12. Hallegatte, S., \& Dumas, P. (2009). Can Natural Disasters have Positive Consequences? Investigating the Role of Embodied Technical Change. Ecological Economics, 68, 777-786.

13. Hansen, H., \& Rand, J. (2006). On the causal links between FDI and growth in developing countries. The World Economy, 29, 21-41.

14. Im, K. S., Pesaran, M. H., \& Shin, Y. (2003). Testing for unit roots in heterogeneous panels. J. Econ., 115, $53 \mathrm{e} 74$.

15. Jemli, R., Chtourou, N., Feki R., \& Bazin D. (2012). La survenue des catastrophes naturelles: classification des variables explicatives par les réseaux de neurones. Ethique et économie.

16. John, W. C., Mitomoa, H., Otsuka, T., \& Stefan, J. (2015). The effects of ICT and mass media in post-disaster recovery - A two model case study of the Great East Japan Earthquake. Telecommunications Policy, 39, $515-532$.

17. Kao, C. (1999). Spurious regression and residual-based tests for cointegration in panel data. J. Econ., 90, 1e44.

18. Levin, A., Lin, C. F., \& Chu, C. (2002). Unit root tests in panel data: asymptotic and finite sample Properties. J. Econ., 108, 1e24.

19. Mahmoodi, M., \& Mahmoodi, E. (2016). Foreign direct investment, exports and economic growth: evidence from two panels of developing countries. Economic Research - Ekonomska Istraživanja, 29(1), 938-949.

20. Mark, N. C., \& Sul, D. (2002). Cointegration vector estimation by panel DOLS and long-run money demand (NBER Technical Working Papers 0287). National Bureau of Economic Research, Inc.

21. Miankhel, A. K., Thangavelu, S. M., \& Kalirajan, K. (2009). Foreign direct investment, exports, and economic growth in selected emerging countries: Multivariate VAR analysis (MPRA Paper, No. 22763).

22. Noy, I. (2009). The Macroeconomic Consequences of Disasters. Journal of Development Economics, 88, $221-231$.

23. Omri, A., \& Kahouli, B. (2014). Causal relationships between energy consumption, foreign direct investment and economic growth: Fresh evidence from dynamic simultaneous-equations models. Energy Policy, 67, 913-922.

24. Pedroni, P. (1997). Panel Cointegration, Asymptotic and Finite Sample Properties of Pooled Time Series Tests with an Application to the PPP Hypothesis: New Results (Working Paper in Economics). Indiana University.

25. Pedroni, P. (1999). Critical values for cointegration tests in heterogeneous panels with multiple regressors. Oxf. Bull. Econ. Stat. 61, 635-670.

26. Pedroni, P. (2001). Purchasing power parity tests in cointegrated panels. Rev. Econ. Stat., 83, 727-731.

27. Pedroni, P. (2004). Panel cointegration. Asymptotic and finite sample properties of pooled time series tests with an application to the PPP hypothesis. Econ. Theory, 20, 597-625.

28. Red Cross Report (2010). Tsunami five-year progress report. Retrieved from http://www.ifrc.org/PageFiles/113868/Tsunami_5Yrs_Report_FR.pdf

29. Samarajiva, R., \& Waidyanatha, N. (2009). Two complementary mobile technologies for disaster warning. Info, 11(2), 58-65.

30. Sawada, Y., Bhattacharyay, R., \& Kotera, T. (2011). Aggregate Impacts of Natural and Man-made Disasters: A quantitative comparison (RIETI Discussion Paper Series 11-E-023).

31. Shklovski, I., Palen, L., \& Sutton, J. (2008). Finding community through information and communication technology in disaster response (Conference Paper).

32. Skidmore, M. and \& Toya, H. (2002). Do Natural Disasters Promote Long-run Growth? Economic Inquiry, 40(4), 664-687.

33. Stanley, T. D., Doucouliagos, C., \& Steel, P. (2015). Does ICT Generate Economic Growth? A Meta Regression Analysis. Deakin University, Faculty of Business and Law, School of Accounting, Economics and Finance.

34. Toya, H., \& Skidmore, M. (2015). Information/communication technology and natural disaster vulnerability. Economics Letters, 137, 143-145.

35. United Nations International Strategy for Disaster Reduction (UNISDR) Report (2015). Towards a post-2015 framework for disaster risk reduction. https://www.unisdr.org/files/25129_towardsapost2015frameworkfordisaste.pdf

36. United Nations Report (2010). Situation, challenges and outlook. Retrieved from http://www.un.org/en/peacekeeping/missions/minustah/documents/un_report_haiti_2010_en.pdf 